\title{
Evidence for post-transcriptional regulation by insulin of 3-hydroxy-3-methylglutaryl coenzyme A reductase and sterol synthesis in human mononuclear leucocytes
}

\author{
W. Krone and H. Greten \\ Medizinische Kernklinik und Poliklinik, Universitäts-Krankenhaus Eppendorf, Hamburg, FRG
}

\begin{abstract}
Summary. Incubation of freshly isolated human mononuclear leucocytes in lipid-depleted serum for $4 \mathrm{~h}$ resulted in a twofold increase in 3-hydroxy-3-methylglutaryl coenzyme A (HMG-CoA) reductase activity. Insulin, when added to the incubation medium at concentrations of 10 and $100 \mathrm{nmol} / 1$ at zero time, caused additional increases in the enzyme activity of $30 \%$ and $37 \%$, respectively. The hormone action was not immediate because no effect was observed when insulin was added at $4 \mathrm{~h}$ and activity examined thereafter. Under these conditions sterol synthesis from ${ }^{14} \mathrm{C}$-acetate and tritiated water was strictly proportional to the activity of HMG-CoA reductase. Cycloheximide $(20 \mu \mathrm{g} / \mathrm{ml})$, a translational inhibitor of protein synthesis, prevented the insulin-mediated increase in the enzyme activity and the incorporation of ${ }^{14} \mathrm{C}$-acetate in-
\end{abstract}

to sterols. Cordycepin $(50 \mu \mathrm{g} / \mathrm{ml})$ inhibited messenger RNA synthesis by $>50 \%$, but had no inhibitory effect on the induction of HMG-CoA reductase and sterol synthesis. Low density lipoprotein $(80 \mu \mathrm{g}$ protein $/ \mathrm{ml})$ and complete serum blocked the induction of the enzyme and sterol synthesis from ${ }^{14} \mathrm{C}$-acetate caused by lipid-depleted serum. The insulin-effect, however, remained unchanged. The results suggest that insulin may regulate the de novo synthesis of HMG-CoA reductase and accordingly sterol synthesis at a post-transcriptional level.

Key words. Insulin, 3-hydroxy-3-methylglutaryl coenzyme A, sterol synthesis, human mononuclear leucocytes, post-transcriptional regulation.
Low density lipoprotein (LDL) plays an important role in atherosclerosis [1] which is one of the major causes of morbidity and mortality in patients with diabetes mellitus [2]. Extrahepatic cells catabolize LDL from plasma after binding to high affinity cell surface receptors. The LDL is degraded and the resulting free cholesterol then regulates the activity of the microsomal enzyme 3-hydroxy-3-methylglutaryl coenzyme A (HMG-CoA) reductase, the rate-limiting enzyme of cholesterol synthesis [1]. Recent results suggest that HMG-CoA reductase and cholesterol synthesis in extrahepatic cells are also under hormonal control. Adrenaline, noradrenaline and isoproterenol suppress sterol synthesis in freshly isolated human mononuclear cells [3]. Insulin stimulates HMG-CoA reductase $[4,5]$ and sterol synthesis [4-6] in human fibroblasts. In this study, we have examined the mechanism whereby insulin regulates HMG-CoA reductase and sterol synthesis in freshly isolated human mononuclear leucocytes.

\section{Material and methods}

\section{Isolation and incubation of mononuclear leucocytes}

Mononuclear leucocytes from healthy subjects were isolated by the method of Böyum [7]. Cells were washed with Krebs-Ringer phosphate buffer ( $\mathrm{pH} 7.4)$, containing glucose $(15 \mathrm{mmol} / 1)$. The washed pellet was resuspended and transferred to plastic culture flasks $\left(25 \mathrm{~cm}^{2}\right.$, Falcon, Oxnard, California, USA). Each flask contained $2-5 \times 10^{6}$ cells suspended in Krebs-Ringer phosphate buffer $(\mathrm{pH} 7.4)$, supplemented with glucose $(15 \mathrm{mmol} / 1)$, sodium acetate $(0.5 \mathrm{mmol} / 1)$, Minimum Essential Medium vitamin solution $(20 \mathrm{ml} / 1)$, Minimum Essential Medium amino acid solution without L-glutamine $(10 \mathrm{ml} / 1)$, 100 units penicillin $/ \mathrm{ml}, 100 \mu \mathrm{g}$ streptomycin $/ \mathrm{ml}$ and $40 \%$ complete or lipid-depleted serum (vol/vol). Out-dated AB-negative plasma was obtained from the blood bank and converted to serum by the addition of $0.035 \mathrm{ml}$ calcium chloride $(0.11 \mathrm{mmol} / 1)$ and 1.2 unit thrombin $/ \mathrm{ml}$ plasma (Behring-Werke, Marburg, FRG). Serum complement was inactivated by heating at $56^{\circ} \mathrm{C}$ for $30 \mathrm{~min}$ and the serum was depleted of lipid by the method of McFarlane [8].

\section{Preparation of low density lipoprotein}

Human LDL (density $1.019-1.063 \mathrm{~g} / \mathrm{ml}$ ) was obtained from the plasma of individual healthy subjects and prepared by density gradient centrifugation in sodium bromide [9]. The concentration of LDL is expressed in terms of their protein content. The mass ratio of total cholesterol to protein in the lipoprotein was $1.6: 1$.

\section{Incorporation of $\left(2-{ }^{3} H\right)$-adenosine into cytoplasmic poly $(A)$ containing $R N A$}

Cells $\left(2 \times 10^{6}\right)$ were labelled with $\left(2-{ }^{3} \mathrm{H}\right)$-adenosine $(100 \mu \mathrm{Ci}, 23 \mathrm{Ci} /$ mmol) for $40 \mathrm{~min}$. Ribosomal-RNA synthesis and mitochondrial RNA synthesis were first suppressed with actinomycin $\mathrm{D}(0.04 \mu \mathrm{g} / \mathrm{ml})$ [10] and ethidium bromide $(1 \mu \mathrm{g} / \mathrm{ml})$ [11], respectively. Actinomycin $\mathrm{D}$, ethidium bromide and cordycepin were added $30 \mathrm{~min}$ before 
Table 1. Effect of insulin on the activity of HMG-CoA reductase and the rate of sterol synthesis from ${ }^{14} \mathrm{C}$-acetate in human mononuclear leucocytes

\begin{tabular}{lll}
\hline Insulin $(\mathrm{nmol} / 1)$ & $\begin{array}{l}\text { HMG-CoA } \\
\text { reductase } \\
\text { activity }(\%)\end{array}$ & $\begin{array}{l}\text { Sterol } \\
\text { synthesis rate } \\
(\%)\end{array}$ \\
\hline 0 & 100 & 100 \\
1 at $0 \mathrm{~h}$ & $106 \pm 3$ & $107 \pm 3$ \\
10 at $0 \mathrm{~h}$ & $130 \pm 3^{\mathrm{a}}$ & $127 \pm 4^{\mathrm{a}}$ \\
$10^{2}$ at $0 \mathrm{~h}$ & $137 \pm 4^{\mathrm{a}}$ & $135 \pm 3^{\mathrm{a}}$ \\
$10^{2}$ at $4 \mathrm{~h}$ & $98 \pm 2$ & $102 \pm 4$ \\
\hline
\end{tabular}

Results are expressed as mean \pm SEM of duplicate incubations in six to ten experiments. Control values: HMG-CoA reductase activity was $0.41 \pm 0.02$ and $0.79 \pm 0.04 \mathrm{pmol} / \mathrm{min}$ per $\mathrm{mg}$ protein at 0 and $4 \mathrm{~h}$, respectively. Sterol synthesis rate from ${ }^{14} \mathrm{C}$-acetate was $1900 \pm 110$ and $3700 \pm 210 \mathrm{cpm} / \mathrm{h}$ per $10^{7}$ cells and from ${ }^{3} \mathrm{H}_{2} \mathrm{O}$ was $330 \pm 40$ and $710 \pm 55 \mathrm{cpm} / \mathrm{h}$ per $10^{7}$ cells at 0 and $4 \mathrm{~h}$, respectively.

${ }^{a} p<0.001$

labelling. Cytoplasmic extracts were prepared by harvesting, washing and resuspending cells in $2 \mathrm{ml}$ of hypotonic buffer $(\mathrm{NaCl}: 10 \mathrm{mmol} / \mathrm{l}$, $\mathrm{MgCl}_{2}: 1.5 \mathrm{mmol} / 1$, Tris: $10 \mathrm{mmol} / 1, \mathrm{pH} 7.4$ ), adding Nonidet (NP 40) detergent (British Drug Houses Chemicals, Poole, Dorset, UK) to a final concentration of $0.5 \%$ and agitating with a vortex mixer (Cenco Instrumenten, Breda, The Netherlands) for $30 \mathrm{~s}$. The nuclei were removed by centrifugation at $800 \mathrm{~g}$ for $2 \mathrm{~min}$ [12], and cytoplasmic RNA was extracted by a conventional phenol chloroform procedure [13]. Poly(A)- containing RNA was isolated by binding to oligo(dT)-cellulose. The bound RNA (poly(A) ${ }^{+} \mathrm{RNA}$ ) eluted with a NaCl-free buffer, and the unbound RNA (poly(A)-RNA) was precipitated with two volumes of ethanol at $-20^{\circ} \mathrm{C}$ for $18 \mathrm{~h}$. The precipitates were dissolved in water and the radioactivities in both types of RNA were measured by a liquid scintillation spectrometer (Packard Instruments, Downers Grove, Illinois, USA) using a toluene based scintillant. The recovery of ${ }^{32} \mathrm{P}$-labelled ribosomal RNA was used to correct for procedural losses of tritiated RNA.

\section{Incorporation of $\left(2-{ }^{14} \mathrm{C}\right)$-acetate into sterols}

Cells $\left(2-5 \times 10^{6}\right)$ were incubated at $37^{\circ} \mathrm{C}$ for the appropriate time when $\left(2-{ }^{14} \mathrm{C}\right)$-acetate $(10 \mu \mathrm{Ci}, 55 \mathrm{Ci} / \mathrm{mmol})$ or tritiated water $(10 \mathrm{mCi}$, $5 \mathrm{Ci} / \mathrm{ml}$ ) was added and the incubations continued for a further $2 \mathrm{~h}$. Incubations (final volume: $2 \mathrm{ml}$ ) were terminated by the addition of $7.5 \mathrm{ml}$ of chloroform/methanol $(1: 2) \cdot\left(1,2{ }^{3} \mathrm{H}\right)$-cholesterol was added as an internal standard when ${ }^{14} \mathrm{C}$-acetate was used. Lipids were extracted by the method of Bligh and Dyer [14] and saponified with methanolic $\mathrm{KOH}(2 \mathrm{~mol} / \mathrm{l})$ for $6 \mathrm{~h}$ at $70^{\circ} \mathrm{C}$. The non-saponifiable fraction was extracted with hexane and the radioactivity measured by liquid scintillation spectrometry using a toluene-based scintillant. The scintillation fluid consisted of 2-5-diphenyloxazole $(5 \mathrm{~g} / 1)$ and 1,4-bis(2-(4-methyl-5-phenyloxazoyl)) benzene $(0.5 \mathrm{~g} / 1)$ in toluene. Two volumes of this solution were added to one volume of Triton X-100 scintillation grade (British Drug Houses Chemicals). The recovery of $\left(1,2-{ }^{3} \mathrm{H}\right)$-cholesterol was used to correct for procedural losses of radioactive non-saponifiable lipids.

\section{Assay of $H M G-C o A$ reductase}

$\left(3-{ }^{14} \mathrm{C}\right)-\mathrm{HMG}$ was converted to the anhydride by the method of Goldfarb and Pitot [15] and $\left(3-{ }^{14} \mathrm{C}\right)$-HMG-CoA prepared from the anhydride according to the method of Hilz et al. [16]. The rate of conversion of $\left(3-{ }^{14} \mathrm{C}\right)$-HMG-CoA to ${ }^{14} \mathrm{C}$-labelled mevalonate was measured in cell extracts using the method of Young and Berger [17]. HMGCoA reductase activity is expressed as pmol of mevalonate formed per min per mg of cell protein. Protein was determined according to the method of Lowry et al. [18] using bovine albumin as a standard.

\section{Materials}

$\left(2-{ }^{3} \mathrm{H}\right)$-adenosine, $\left(2-{ }^{14} \mathrm{C}\right)$-acetate, $\left(3-{ }^{-14} \mathrm{C}\right)-\mathrm{HMG}$, tritiated water and $\left(1,2{ }^{3} \mathrm{H}\right)$-cholesterol were purchased from Amersham International, Amersham, Bucks, UK. Cordycepin and cycloheximide were obtained from Sigma Chemicals, St. Louis, Missouri, USA. Insulin was purchased from Novo, Copenhagen, Denmark.

\section{Statistical analysis}

Results are expressed as mean \pm SEM and significance of differences was calculated by the Student's paired t-test

\section{Results}

Sterol synthesis in mononuclear leucocytes was measured by the incorporation of ${ }^{14} \mathrm{C}$-acetate into non-saponifiable lipids. Because of the possibility that treatment of cells with insulin, cordycepin or cycloheximide could alter the pool size of acetate, an initial comparison was made between ${ }^{14} \mathrm{C}$-acetate and tritiated water as precursor substrates. Parallel results were obtained using either substrate.

\section{Effect of insulin on $H M G-C o A$ reductase and sterol synthesis}

Incubation of freshly isolated human mononuclear leucocytes for $4 \mathrm{~h}$ in a medium containing lipid-depleted serum resulted in a twofold increase in HMG-CoA reductase activity. The difference between enzyme activity at 0 and $4 \mathrm{~h}$ was defined as $100 \%$. Insulin, added to the incubation medium at concentrations of 10 and $100 \mathrm{nmol} / 1$ at zero-time, led to further increases in the enzyme activity of $30 \%$ and $37 \%$, respectively (Table 1 ). Under these conditions, sterol synthesis from ${ }^{14} \mathrm{C}$-acetate was strictly proportional to the activity of $\mathrm{HMG}^{-}$ CoA reductase (Table 1 ).

The action of insulin on HMG-CoA reductase and sterol synthesis was not immediate because the hormone given at $4 \mathrm{~h}$ to the medium had an effect neither on the enzyme activity nor on the incorporation of ${ }^{14} \mathrm{C}$ acetate into sterols (Table 1).

\section{Effects of $L D L$ and complete serum on the insulin- mediated induction of $\mathrm{HMG}-\mathrm{CoA}$ reductase and sterol synthesis}

LDL, when added in increasing concentrations to the incubation medium, diminished or blocked the induction of HMG-CoA reductase and sterol synthesis caused by lipid-depleted serum (Fig.1). However, the lipoprotein did not suppress the insulin-effect on either the enzyme activity or the rise in ${ }^{14} \mathrm{C}$-acetate incorporation into sterols (Fig.1). When the cells were incubated for $4 \mathrm{~h}$ in the presence of complete serum, HMG-CoA reductase and the rate of sterol synthesis remained suppressed. However, insulin added to the medium at a 


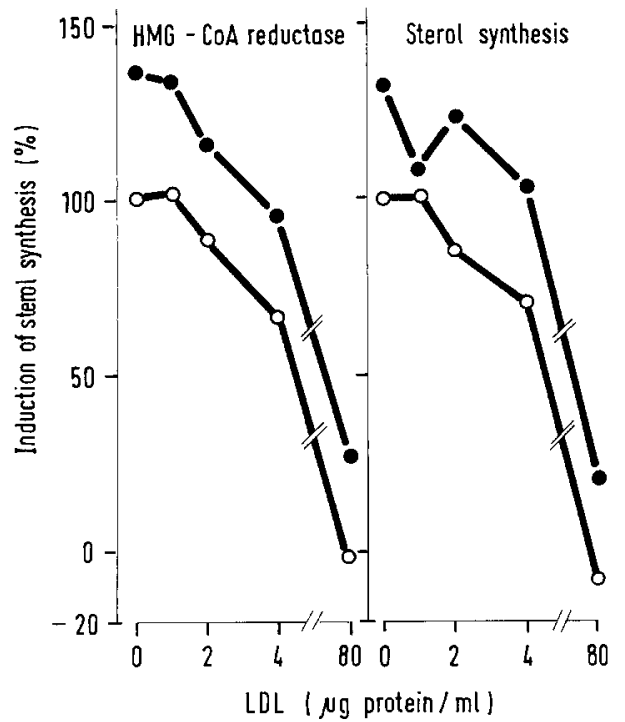

Fig. 1. Effect of LDL on the insulin-mediated induction of HMG$\mathrm{CoA}$ reductase and sterol synthesis from ${ }^{14} \mathrm{C}$-acetate in human mononuclear leucocytes. Cells were incubated at $37^{\circ} \mathrm{C}$ in a medium containing lipid-depleted serum for either 0 or $4 \mathrm{~h}$ before measurement of enzyme activity or labelling with acetate. Insulin $(100 \mathrm{nmol} / \mathrm{l})$ and LDL in varying concentrations were added at the beginning of the incubation. HMG-CoA reductase activity and incorporation of ${ }^{14} \mathrm{C}$-acetate into sterols were measured as described in Materials and methods. One hundred percent induction was defined as the difference between enzyme activity or sterol synthesis at 0 and $4 \mathrm{~h}$ without hormone. -0 ; -0 , represent the mean respectively of duplicate incubations with and without insulin in one experiment which was representative of four. Control values: $\mathrm{HMG}-\mathrm{Co} A$ reductase was 0.44 and $0.86 \mathrm{pmol} / \mathrm{min}$ per mg protein and sterol synthesis rate was 2110 and $4040 \mathrm{cpm} / \mathrm{h}$ per $10^{7}$ cells at 0 and $4 \mathrm{~h}$, respectively

concentration of $100 \mathrm{nmol} / 1$ at zero-time caused a statistically significant rise after $4 \mathrm{~h}$ in the enzyme activity and in sterol synthesis from ${ }^{14} \mathrm{C}$-acetate compared with controls (data not shown).

Effects of cycloheximide and cordycepin on the insulinmediated induction of HMG-CoA reductase and sterol synthesis

Cycloheximide not only prevented the induction of the enzyme and sterol synthesis from ${ }^{14} \mathrm{C}$-acetate caused by lipid-depleted serum in mononuclear leucocytes but also suppressed the insulin-effect on both (Table 2). Cordycepin at concentrations from 12.5 to $50 \mu \mathrm{g} / \mathrm{ml}$ added to mononuclear leucocytes $30 \mathrm{~min}$ before the addition of ${ }^{3} \mathrm{H}$-adenosine inhibited the appearance of the isotope in cytoplasmic poly(A)-containing RNA, which in mammalian cells represents messenger RNA [19]. The inhibition was $>50 \%$ at a concentration of $50 \mu \mathrm{g} / \mathrm{ml}$. In contrast, cordycepin had no effect on the incorporation of label into cytoplasmic RNA containing no poly(A)-sequences (Table 3$)$. Although cordycepin $(50 \mu \mathrm{g} /$ ml) inhibited messenger RNA synthesis by $>50 \%$, it had no inhibitory effect on the induction of HMG-CoA reductase and sterol synthesis from ${ }^{14} \mathrm{C}$-acetate by insu-
Table 2. Effects of cycloheximide and cordycepin on the insulin-mediated induction of $\mathrm{HMG}$-CoA reductase and sterol synthesis from ${ }^{14} \mathrm{C}$ acetate in human mononuclear leucocytes

\begin{tabular}{llc}
\hline Agent & $\begin{array}{l}\text { HMG-CoA } \\
\text { reductase activity } \\
(\%)\end{array}$ & $\begin{array}{l}\text { Sterol } \\
\text { synthesis rate } \\
(\%)\end{array}$ \\
\hline None & 100 & 100 \\
Insulin & $136 \pm 4^{\mathrm{a}}$ & $140 \pm 4^{\mathrm{a}}$ \\
Cycloheximide & $48 \pm 2^{\mathrm{a}}$ & $45 \pm 3^{\mathrm{a}}$ \\
Insulin + cycloheximide & $46 \pm 2^{\mathrm{a}}$ & $47 \pm 2^{\mathrm{a}}$ \\
Insulin & $134 \pm 3^{\mathrm{a}}$ & $136 \pm 3^{\mathrm{a}}$ \\
Cordycepin & $102 \pm 2$ & $99 \pm 3$ \\
Insulin + cordycepin & $133 \pm 4^{\mathrm{a}}$ & $136 \pm 4^{\mathrm{a}}$ \\
\hline
\end{tabular}

Results are expressed as mean \pm SEM of duplicate incubations in six to eight experiments. Control values: $\mathrm{HMG}-\mathrm{CoA}$ reductase activity was $0.37 \pm 0.02 \mathrm{pmol} / \mathrm{min}$ per $\mathrm{mg}$ protein at $0 \mathrm{~h}$ and $0.78 \pm$ $0.04 \mathrm{pmol} / \mathrm{min}$ per $\mathrm{mg}$ at $4 \mathrm{~h}$. Sterol synthesis rate: $2020 \pm 120 \mathrm{cpm} / \mathrm{h}$ per $10^{7}$ cells at $0 \mathrm{~h}$ and $4200 \pm 230 \mathrm{cpm} / \mathrm{h}$ per $10^{7}$ cells at $4 \mathrm{~h}$.

a $p<0.001$

Table 3. Effect of cordycepin on the incorporation of ${ }^{3} \mathrm{H}$-adenosine into cytoplasmic poly $(\mathrm{A})$-containing RNA (messenger RNA) and into RNA without poly(A)-sequences in human mononuclear leucocytes

\begin{tabular}{lcc}
\hline Cordycepin $(\mu \mathrm{g} / \mathrm{ml})$ & \multicolumn{2}{l}{$\begin{array}{l}\left.{ }^{3} \mathrm{H} \text {-adenosine (cpm } / 10^{6} \text { cells }\right) \\
\text { incorporated into: }\end{array}$} \\
\cline { 2 - 3 } & Poly(A) ${ }^{+}$RNA & Poly(A)-RNA \\
\hline 0 & $1420 \pm 70$ & $9200 \pm 800$ \\
12.5 & $930 \pm 130$ & $9750 \pm 750$ \\
25.0 & $840 \pm 100$ & $9000 \pm 500$ \\
50.0 & $700 \pm 70$ & $10000 \pm 450$ \\
\hline
\end{tabular}

Results expressed as mean \pm SEM for three to four experiments

lin in cells which were incubated in the presence of lipid-depleted serum (Table 2).

\section{Discussion}

The activity of the microsomal enzyme HMG-CoA reductase determines the rate of cholesterol synthesis in a variety of mammalian cells [20]. When human mononuclear leucocytes are incubated for several hours in a medium containing lipid-depleted serum, HMG-CoA reductase activity increases several fold. Subsequent addition of LDL is followed by suppression of the enzyme activity. Under these conditions, the rate of incorporation of ${ }^{14} \mathrm{C}$-acetate into sterols is strictly proportional to the activity of $\mathrm{HMG}$-CoA reductase [21].

The present study demonstrates that insulin raises the activity of HMG-CoA reductase and correspondingly increases the rate of sterol synthesis in human mononuclear leucocytes, despite maximally effective concentrations of lipid-depleted serum in the incubation medium. Addition of LDL or complete serum to the incubation medium prevented the induction of both the enzyme and sterol synthesis caused by lipid-depleted serum, but did not alter the insulin-effect. These re- 
sults are in contrast to those obtained in human fibroblasts showing that in the presence of fetal calf serum insulin failed to increase $\mathrm{HMG}-\mathrm{CoA}$ reductase activity [22].

It is interesting to note that insulin required some time to exert its stimulatory action on HMG-CoA reductase and accordingly sterol synthesis. This result suggests that the hormone may stimulate de novo synthesis of the enzyme as does lipid-depleted serum [21, 22]. This hypothesis was tested using the translational inhibitor of protein synthesis, cycloheximide, and the inhibitor of messenger RNA synthesis, cordycepin. Cycloheximide prevented the insulin-mediated induction of HMG-CoA reductase and sterol synthesis, indicating a dependence on protein synthesis. Although the mechanism of cordycepin at the molecular level is still being debated [23], the effect of the drug in HeLa cells [12], mouse sarcoma 180 cells [24] and in cultured human fibroblasts [25] is seen as inhibiting messenger RNA synthesis. Cordycepin, despite its ability to inhibit messenger RNA synthesis by more than $50 \%$ in human mononuclear leucocytes, had no inhibitory effect on the induction of the enzyme and sterol synthesis by insulin. Assuming that the synthesis of messenger RNA for the rate-limiting enzyme of cholesterol and total messenger RNA synthesis were similarly inhibited by cordycepin, our results suggest that the induction of HMG-CoA reductase by insulin is independent of newly synthesized messenger RNA. The latter implies that insulin may regulate HMG-CoA reductase and accordingly sterol synthesis at a post-transcriptional level.

Acknowledgement. This work was supported by Fr. Thyssen Stiftung. We thank Mrs. A. Vecsei for excellent technical assistance.

\section{References}

1. Goldstein JL, Brown MS (1977) The low density lipoprotein pathway and its relation to atherosclerosis. Ann Rev Biochem 46: $897-930$

2. Stout RW (1979) Diabetes and atherosclerosis - the role of insulin. Diabetologia 16: 141-150

3. Krone W, Hildebrandt F, Greten H (1982) Effect of catecholamines on sterol synthesis in human mononuclear cells. Eur J Clin Invest 12: 467-471

4. Brown MS, Dana SE, Goldstein JL (1974) Regulation of 3-hydroxy-3-methylglutaryl coenzyme A reductase activity in cultured human fibroblasts. J Biol Chem 249: 789-796

5. Bhathena SJ, Avigan J, Schreiner ME (1974) Effect of insulin on sterol and fatty acid synthesis and hydroxy-methylglutaryl CoA reductase activity in mammalian cells grown in culture. Proc Natl Acad Sci USA 71: 2174-2178

6. Chait A, Bierman EL, Albers JJ (1979) Low density lipoprotein receptor activity in cultured human skin fibroblasts. Mechanism of insulin-induced stimulation. J Clin Invest 64: 1309-1319
7. Böyum A (1968) Isolation of mononuclear cells and granulocytes from human blood. Scand J Clin Lab Invest 97 (Suppl 21): 77-89

8. McFarlane AS (1968) Behaviour of lipids in human serum. Nature 149: 439

9. Hinton RH, Al-Tamar Y, Mallinson A, Marks V (1974) The use of density gradient centrifugation for the centrifugation of the serum lipoprotein. Clin Chim Acta 53: 355-360

10. Perry RP (1963) Selective effects of actinomycin $D$ on the intracellular distribution of RNA synthesis in tissue culture cells. Exp Cell Res 29: 400-406

11. Zylber E, Vesco C, Penman S (1969) Selective inhibition of the synthesis of mitochondria-associated RNA by ethidium bromide. J Mol Biol 44: 195-204

12. Penman S, Rosbash M, Penman M (1970) Messenger and heterogenous nuclear RNA in HeLa cells: differential inhibition by cordycepin. Proc Natl Acad Sci USA 67: 1878-1885

13. Rudland FS, Weil S, Hunter AR (1975) Changes in RNA metabolism and accumulation of presumptive messenger RNA during transition from the growing to the quiescent state of cultured mouse fibroblasts. J Mol Biol 96: 745-766

14. Bligh EG, Dyer WJ (1959) A rapid method of total lipid extraction and purification. Can J Biochem Physiol 37: 911-917

15. Goldfarb S, Pitot HC (1974) Improved assay of 3-hydroxy-3methylglutaryl CoA reductase. J Lipid Res 12: 512-514

16. Hilz H, Knappe J, Ringelman E, Lynen F (1958) Methylglutaconase, eine neue Hydratase, die am Stoffwechsel verzweigter Carbonsäuren beteiligt ist. Biochem Z 329: 476-489

17. Young NL, Berger B (1981) Assay of S-3-hydroxy-3-methylglutaryl-CoA reductase. In: Lowenstein JM (ed) Methods in enzymology; No. 71, part C. Academic Press, New York, pp 498-509

18. Lowry OH, Rosenbrough NH, Farr AJ, Randall RJ (1951) Protein measurement with the folin phenol reagent. J Biol Chem 193: 264-275

19. Lewin B (1975) Limits of transcription and translation: the relationship between the heterogenous nuclear RNA and messenger RNA. Cells 4: 11-20

20. Rodwell VW, Nordstrom JL, Mitschelen JJ (1976) Regulation of HMG-CoA reductase. Adv Lipid Res 14: 1-74

21. Krone W, Betteridge DJ, Galton DJ (1979) Mechanism of regulation of 3-hydroxy-3-methylglutaryl coenzyme A reductase activity by low density lipoprotein in human lymphocytes. Eur J Clin Invest $9: 405-410$

22. Brown MS, Dana SE, Goldstein JL (1973) Regulation of 3-hydroxy-3-methylglutaryl coenzyme A reductase activity in human fibroblasts by lipoprotein. Proc Natl Acad Sci USA 70:2162-2166

23. Maale G, Stein G, Mans R (1975) Effects of cordycepin and cordycepin triphosphate on poly-adenylic and ribonucleic acid-synthesizing enzymes from eukaryotes. Nature 255: 80-82

24. Mendecki J, Lee SY, Brawerman G (1972) Characteristics of the polyadenylic acid segment associated with messenger ribonucleic acid in mouse sarcoma 180 ascites cells. Biochemistry 11: 792-798

25. Cholon JJ, Studzinski GP (1974) Metabolic differences between normal and neoplastic cells: effects of aminonucleoside on cytoplasmic messenger RNA. Science 184: 160-161

Received: 30 March 1983

and in revised form: 2 February 1984

PD Dr. W. Krone

Medizinische Kernklinik und Poliklinik

Universitäts-Krankenhaus Eppendorf

Martinistraße 52

D-2000 Hamburg 20

FRG 